\title{
PROFIL KETEPATAN PENGGUNAAN ANTIBIOTIK PADA KARYAWAN UNIVERSITAS TARUMANAGARA
}

\author{
Bernadetha Vania Eveliani', Shirly Gunawan ${ }^{2}$ \\ ${ }^{1}$ Alumnus Fakultas Kedokteran Universitas Tarumanagara \\ Email: vania.bernadetha@yahoo.com \\ ${ }^{2}$ Bagian Farmakologi Fakultas Kedokteran Universitas Tarumanagara \\ Email:shirlyg@fk.untar.ac.id
}

Masuk : 10-03-2021, revisi: 28-04-2021, diterima untuk diterbitkan : 29-05-2021

\begin{abstract}
ABSTRAK
Antibiotik merupakan salah satu golongan obat yang banyak digunakan di Indonesia. Data Riskesdas menunjukkan cukup banyak masyarakat yang menyimpan antibiotik di rumah tangga dimana sebagian besar diperoleh tanpa resep dokter. Banyak masyarakat yang melakukan pengobatan sendiri (swamedikasi). Tingginya angka penggunaan antibiotik tanpa resep dokter membuat penggunaannya menjadi irasional dan berdampak pada timbulnya resistensi obat. Salah satu faktor penyebabnya ialah kurangnya pengetahuan masyarakat mengenai penggunaan obat, khususnya antibiotik. Studi ini bertujuan untuk mengetahui gambaran ketepatan penggunaan dan tingkat pengetahuan mengenai antibiotik pada karyawan Universitas Tarumanagara. Studi ini bersifat deskriptif, dilakukan dengan desain cross sectional survey. Pengumpulan data dilakukan melalui pemberian kuesioner terhadap 114 orang responden. Dari hasil penelitian ini diketahui sebagian besar responden yaitu sebanyak 104 orang (91,2\%) mengonsumsi antibiotik amoxycillin. Ketepatan dalam penggunaan antibiotik dinilai dari ketepatan dosis, frekuensi minum obat dan lama pemberian obat. Hasil studi menunjukkan sebanyak $100 \%$ responden telah mengonsumsi antibiotik dengan dosis tepat. Sebagian besar responden tepat mengonsumsi obat sesuai frekuensi yang dianjurkan $(88,6 \%)$, dan $93,9 \%$ tepat mengonsumsi antibiotik sesuai dengan lama waktu yang seharusnya. Secara umum dapat dinilai sebanyak $70,2 \%$ responden telah menggunakan antibiotik dengan tepat dan $47,4 \%$ responden memiliki pengetahuan "baik" mengenai antibiotik. Masih ada sebagian responden yang menggunakan antibiotik dengan tidak tepat sehingga perlu ditingkatkan pengetahuan mengenai antibiotik supaya tidak terjadi resistensi antibiotik.
\end{abstract}

Kata Kunci : antibiotik, penggunaan antibiotik, tingkat pengetahuan.

\begin{abstract}
Antibiotics are widely used in Indonesia. Riset Kesehatan Dasar (Riskesdas) shows that some people store antibiotics at home, most of which are obtained without a doctor's prescription. Many people do self-medication. The high rate of use of antibiotics without a doctor's prescription makes their use irrational and impacts the emergence of drug resistance. One of the contributing factors is the lack of public knowledge about the use of drugs, especially antibiotics. This study aims to describe the accuracy of the use and level of knowledge about antibiotics in Tarumanagara University employees. This study is descriptive, conducted with a cross-sectional survey design. Data was collected through the provision of questionnaires to 114 respondents. This study showed that most of the respondents, as many as 104 people (91.2\%), took amoxicillin antibiotics. The accuracy of antibiotics-using is assessed by determining the accuracy of the dose, frequency of drug-taking, and duration of drug administration. The study results showed that as many as 100\% of the respondents had taken the correct dose of antibiotics. Most of the respondents took the right medicine according to the recommended frequency (88.6\%) and duration (93.9\%). The study showed that $70.2 \%$ of respondents had used antibiotics correctly, and $47.4 \%$ of respondents have "good" knowledge about antibiotics. Some respondents still misuse antibiotics, so that knowledge about antibiotics needs to be increased so that antibiotic resistance does not occur.
\end{abstract}

Keywords: antibiotics, antibiotic use, level of knowledge

\section{PENDAHULUAN}

Antibiotik adalah zat kimia yang dihasilkan oleh mikroorganisme yang mempunyai kemampuan untuk menghambat pertumbuhan atau membunuh mikroorganisme. ${ }^{1}$ Zaman sekarang masyarakat dengan mudah dapat membeli antibiotik tanpa resep dokter. Menurut penelitian dari Aris Widayati et al, di Yogyakarta terdapat sekitar $64 \%$ pembelian antibiotik tanpa resep dokter. ${ }^{2}$ 
Pelayanan pembelian antibiotik secara bebas oleh penyedia obat mendorong perilaku swamedikasi (pengobatan sendiri) antibiotik. ${ }^{3}$

Pengetahuan seseorang mengenai antibiotik akan mempengaruhi perilaku dalam penggunaannya. Kurangnya pengetahuan dapat berdampak pada perilaku pengobatan yang tidak tepat sehingga kualitas pengobatan pun berkurang. Hasil Riset Kesehatan Dasar tahun 2013 menunjukkan bahwa 35,2\% masyarakat Indonesia menyimpan obat di rumah tangga, di antaranya sebesar $27,8 \%$ adalah antibiotik. Dari jumlah tersebut, $86,1 \%$ menyimpan antibiotik yang diperoleh tanpa resep. ${ }^{4}$ Menurut data pengobatan periode 10 Juli 2014 - 10 Juli 2015 di Pos Kesehatan Universitas Tarumanagara,ditemukan $44,27 \%$ penggunaan antibiotik yang tepat dengan kasus terbanyak infeksi saluran pernapasan akut (ISPA). Antibiotik yang banyak digunakan meliputi 45,72\% Amoxycillin, 27,04\% Ciprofloxacin, dan 18,87\% Cefadroxil.

Intensitas penggunaan antibiotik yang relatif tinggi dalam masyarakat menimbulkan berbagai masalah dan menjadi ancaman bagi kesehatan seperti resistensi bila penggunaanya tidak tepat. Selain itu, hal ini berdampak pula pada tingkat morbiditas dan mortalitas masyarakat serta peningkatan biaya perawatan kesehatan. Oleh karena itu, penulis tertarik untuk melakukan penelitian tentang profil ketepatan penggunaan antibiotik pada karyawan Universitas Tarumanagara. Tujuan penelitian ini adalah diketahuinya profil ketepatan penggunaan antibiotik pada karyawan Universitas Tarumanagara melalui gambaran penggunaan antibiotik dan tingkat pengetahuan mengenai antibiotik.

\section{METODE PENELITIAN}

Desain penelitian yang digunakan pada penelitian ini adalah deskriptif cross-sectional. Penelitian ini dilakukan di lingkungan Universitas Tarumanagara pada Januari 2016 - Februari 2016 dengan jumlah sampel sebanyak 114 karyawan Universitas Tarumanagara yang memenuhi kriteria inklusi selama penelitian. Digunakan teknik stratified random sampling dalam proses pengambilan sampel.

Kriteria inklusi dalam penelitian ini adalah karyawan Universitas Tarumanagara yang masih aktif bekerja (laki-laki dan perempuan), sedang atau pernah mengonsumsi antibiotik, bersedia terlibat dalam penelitian, menandatangani informed consent, dan mengisi kuesioner. Cara kerja pada penelitian ini adalah peneliti mencari responden (karyawan Universitas Tarumanagara) yang memenuhi kriteria inklusi dan dilakukan pengambilan data dengan pengisian kuesioner, lalu data tersebut diolah dan menyusun laporan penelitian.

Variabel yang dinilai dalam penelitian ini adalah usia, jenis kelamin, pendidikan terakhir, pekerjaan, jenis antibiotik, ketepatan penggunaan antibiotik, efek samping antibiotik, cara mendapatkan antibiotik, hasil terapi, penggunaan antibiotik, dan pengetahuan mengenai antibiotik. Instrumen penelitian yang digunakan adalah kuesioner yang terdiri dari data demografi responden (bagian I), 10 pernyataan mengenai penggunaan antibiotik pada responden (bagian II), dan 20 pernyataan mengenai pengetahuan antibiotik (bagian III).

Pengumpulan data dilakukan oleh 1 orang peneliti. Responden penelitian yang dipilih adalah karyawan Universitas Tarumanagara yang telah memenuhi kriteria inklusi. Penelitian ini dilakukan dengan mengumpulkan data-data primer responden melalui pengisian kuesioner untuk mendapatkan informasi mengenai profil ketepatan penggunaan antibiotik. 
Analisis data dilakukan menggunakan sistem skoring pada kuesioner, dimana jawaban benar bernilai 1 dan jawaban salah bernilai 0 . Nilai skoring pada pernyataan penggunaan antibiotik didapatkan dengan rumus $\frac{\text { skoryangdiperoleh }}{\text { skortotal }} x 100 \%$. Nilai tersebut dievaluasi dengan pedoman skoring aspek tindakan: $76-100 \%$ baik, $56-75 \%$ sedang, dan $<56 \%$ buruk. Nilai skoring pada pernyataan pengetahuan mengenai antibiotik didapatkan dengan rumus $\frac{\text { skoryangdiperoleh }}{\text { skortotal }} x 10$. Nilai tersebut dievaluasi dengan pedoman skoring tingkat pengetahuan: 8,1-10 baik sekali, 6,68,0 baik, 5,6-6,5 cukup, 4,0-5,5 kurang, dan <4,0 tidak baik.

\section{HASIL DAN PEMBAHASAN}

\section{Karakteristik Responden}

Pengumpulan data penelitian ini dilakukan terhadap 114 karyawan Universitas Tarumanagara yang telah bersedia terlibat dalam penelitian setelah penjelasan dan mengisi informed consent. Distribusi karakteristik responden berdasarkan usia, jenis kelamin, pendidikan terakhir, dan pekerjaan dapat dilihat pada tabel 1 .

\begin{tabular}{ccc}
\multicolumn{3}{c}{ Tabel 1 Distribusi Karakteristik Responden } \\
\hline Karakteristik & $\begin{array}{c}\text { Jumlah } \\
(\mathrm{n}=114)\end{array}$ & $\begin{array}{c}\text { Persentase } \\
(\%)\end{array}$ \\
\hline Usia (tahun) & & \\
$<21$ & 2 & $1.8 \%$ \\
$21-30$ & 3 & $2.6 \%$ \\
$31-40$ & 15 & $13.2 \%$ \\
$41-50$ & 60 & $52.6 \%$ \\
$>$ 50 & 34 & $29.8 \%$ \\
Jenis Kelamin & & \\
Laki-laki & 80 & $70.2 \%$ \\
Perempuan & 34 & $29.8 \%$ \\
Pendidikan Terakhir & \\
SD & 1 & $0.9 \%$ \\
SMP & 2 & $1.8 \%$ \\
SMA / & & \\
SMK / & 67 & $58.8 \%$ \\
STM & & \\
D3 & 7 & $6.1 \%$ \\
S1 & 32 & $28.1 \%$ \\
S2 & 5 & $4.4 \%$ \\
Pekerjaan & & \\
Universitas & 48 & $42.1 \%$ \\
FE & 18 & $15.8 \%$ \\
FH & 6 & $5.3 \%$ \\
FT & 17 & $4.9 \%$ \\
FK & 6 & $5.3 \%$ \\
FPsi & 4 & $3.5 \%$ \\
FSRD & 5 & $4.4 \%$ \\
FTI & 3 & $2.6 \%$ \\
\hline
\end{tabular}




\begin{tabular}{lcc}
\hline Karakteristik & $\begin{array}{c}\text { Jumlah } \\
(\mathrm{n}=114)\end{array}$ & $\begin{array}{c}\text { Persentase } \\
(\%)\end{array}$ \\
\hline Pekerjaan & & \\
Fikom & 3 & $2.6 \%$ \\
Program & 4 & $3.5 \%$ \\
Pascasarjana & 4 & \\
\hline
\end{tabular}

Ket. $\mathrm{FE}=$ Fakultas Ekonomi, $\mathrm{FH}=$ Fakultas Hukum, FT $=$ Fakultas Teknik, FK $=$ Fakultas Kedokteran, FPsi $=$ Fakultas Psikologi, FSRD $=$ Fakultas Seni Rupa dan Desain, FTI $=$ Fakultas Teknologi Informasi, Fikom = Fakultas Ilmu Komunikasi

\section{Gambaran Penggunaan Antibiotik}

Jenis Antibiotik

Pada 114 karyawan Universitas Tarumanagara yang telah bersedia menjadi responden dalam penelitian didapatkan seluruhnya pernah atau sedang mengonsumsi antibiotik.

\begin{tabular}{lcc}
\multicolumn{3}{c}{ Tabel 2 Jenis Antibiotik } \\
\hline \multicolumn{1}{c}{ Jenis } & $\begin{array}{c}\text { Jumlah } \\
(\mathrm{n}=114)\end{array}$ & $\begin{array}{c}\text { Persentase } \\
(\%)\end{array}$ \\
\hline Amoxycillin & 104 & $91.2 \%$ \\
Ciprofloxacin & 1 & $0.9 \%$ \\
Cefadroxil & 6 & $5.3 \%$ \\
Tetracycline & 3 & $2.6 \%$ \\
Lain-lain & 0 & $0.0 \%$ \\
\hline
\end{tabular}

\section{Ketepatan Penggunaan Antibiotik}

Ketepatan penggunaan antibiotik pada 114 responden dapat dilihat dari ketepatan dosis, ketepatan frekuensi minum obat, dan ketepatan lama pemberian obat.

\begin{tabular}{|c|c|c|}
\hline $\begin{array}{c}\text { Penggunaan } \\
\text { Antibiotik }\end{array}$ & $\begin{array}{l}\text { Jumlah } \\
(\mathrm{n}=114)\end{array}$ & $\begin{array}{c}\text { Persentase } \\
(\%)\end{array}$ \\
\hline \multicolumn{3}{|c|}{ Ketepatan Dosis } \\
\hline Tepat & 114 & $100.0 \%$ \\
\hline Tidak Tepat & 0 & $0.0 \%$ \\
\hline \multicolumn{3}{|c|}{ Ketepatan Frekuensi Minum Obat } \\
\hline Tepat & 101 & $88.6 \%$ \\
\hline Tidak Tepat & 13 & $11.4 \%$ \\
\hline \multicolumn{3}{|c|}{ Ketepatan Lama Pemberian Obat } \\
\hline Tepat & 107 & $93.9 \%$ \\
\hline Tidak Tepat & 7 & $6.1 \%$ \\
\hline
\end{tabular}

\section{Efek Samping Antibiotik}

Dari hasil penelitian terhadap 114 responden didapatkan informasi mengenai efek samping penggunaan antibiotik. 
Tabel 4 Efek Samping Antibiotik

\begin{tabular}{lcc}
\hline $\begin{array}{c}\text { Efek Samping } \\
\text { Obat }\end{array}$ & $\begin{array}{c}\text { Jumlah } \\
(\mathrm{n}=114)\end{array}$ & $\begin{array}{c}\text { Persentase } \\
(\%)\end{array}$ \\
\hline Tidak ada & 78 & $68.4 \%$ \\
Mual muntah & 20 & $17.6 \%$ \\
Diare & 16 & $14.0 \%$ \\
\hline
\end{tabular}

\section{Cara Mendapatkan Antibiotik}

Pada 114 karyawan Universitas Tarumanagara yang telah bersedia menjadi responden dalam penelitian ini didapatkan cara mendapatkan obat, baik dari dokter ataupun membeli di warung.

\begin{tabular}{lcc}
\multicolumn{3}{c}{ Tabel 5 Cara Mendapatkan Antibiotik } \\
\hline $\begin{array}{c}\text { Cara } \\
\text { Mendapatkan } \\
\text { Obat }\end{array}$ & $\begin{array}{c}\text { Jumlah } \\
(\mathrm{n}=114)\end{array}$ & Persentase (\%) \\
\hline Dokter & 105 & $92.1 \%$ \\
Warung & 9 & $7.9 \%$ \\
\hline
\end{tabular}

\section{Hasil Terapi}

Dari hasil penelitian terhadap 114 karyawan Universitas Tarumanagara yang telah bersedia menjadi responden didapatkan informasi mengenai hasil terapi tersebut sembuh atau tidak.

Tabel 6 Hasil Terapi Antibiotik

\begin{tabular}{lcc}
\hline Hasil Terapi & $\begin{array}{c}\text { Jumlah } \\
(\mathrm{n}=114)\end{array}$ & $\begin{array}{c}\text { Persentase } \\
(\%)\end{array}$ \\
\hline Sembuh & 107 & $93.9 \%$ \\
Tidak Sembuh & 7 & $6.1 \%$ \\
\hline
\end{tabular}

\section{Penggunaan Antibiotik}

Pada 114 karyawan Universitas Tarumanagara yang telah bersedia menjadi responden dalam penelitian ini didapatkan bagaimana tingkat penggunaan antibiotik. Penentuan ketepatan penggunaan antibiotik ini didasarkan pertanyaan pada kuesioner, dimana jawaban benar bernilai 1 dan jawaban salah bernilai 0 . Nilai yang diperoleh dihitung dengan rumus $\frac{\text { skoryangdiperoleh }}{\text { skortotal }} \times 100 \%$.

Skor $76-100 \%$ terkategori aspek tindakan baik yang berarti penggunaan antibiotik sudah tepat. Skor 56-75\% terkategori aspek tindakan sedang yang berarti penggunaan antibiotik kurang tepat. Skor $<56 \%$ terkategori aspek tindakan buruk yang berarti penggunaan antibiotik tidak tepat.

\begin{tabular}{ccc} 
Tabel 7 Penggunaan Antibiotik Pada 114 Responden \\
\cline { 2 - 3 } \multicolumn{1}{c}{ Aspek } & Jumlah & Persentase \\
Tindakan & $(\mathrm{n}=114)$ & $(\%)$ \\
\hline Baik & 80 & $70.2 \%$ \\
Sedang & 25 & $21.9 \%$ \\
Buruk & 9 & $7.9 \%$ \\
\hline
\end{tabular}




\section{Pengetahuan Mengenai Antibiotik}

Pada 114 karyawan Universitas Tarumanagara yang telah bersedia menjadi responden dalam penelitian ini didapatkan bagaimana tingkat pengetahuan mengenai antibiotik. Penentuan tingkat pengetahuan ini didasarkan pertanyaan pada kuesioner, dimana jawaban benar bernilai 1 dan jawaban salah bernilai 0. Nilai yang diperoleh dihitung dengan rumus $\frac{\text { skoryangdiperoleh }}{\text { skortotal }} x 10$.

Skor 8,1-10,0 terkategori pengetahuan baik sekali, skor 6,6-8,0 terkategori pengetahuan baik, skor 5,6-6,5 terkategori pengetahuan cukup baik, skor 4,0-5,5 terkategori pengetahuan kurang baik, dan skor $<4,0$ terkategori pengetahuan tidak baik.

Tabel 8 Pengetahuan Mengenai Antibiotik Pada 114 Responden

\begin{tabular}{lcc}
\hline $\begin{array}{c}\text { Tingkat } \\
\text { Pengetahuan }\end{array}$ & $\begin{array}{c}\text { Jumlah } \\
(\mathrm{n}=114)\end{array}$ & $\begin{array}{c}\text { Persentase } \\
(\%)\end{array}$ \\
\hline Baik sekali & 30 & $26.3 \%$ \\
Baik & 54 & $47.4 \%$ \\
Cukup & 18 & $15.8 \%$ \\
Kurang & 10 & $8.8 \%$ \\
Tidak Baik & 2 & $1.8 \%$ \\
\hline
\end{tabular}

\section{PEMBAHASAN}

\section{Karakteristik Responden}

Distribusi karakteristik responden pada penelitian ini berdasarkan usia, jenis kelamin, pendidikan terakhir, dan pekerjaan. Pada pengelompokan berdasarkan usia responden didapatkan paling banyak jumlah responden berumur 41-50 tahun. Pada penelitian Misriana, responden terbanyak berusia 18-60 tahun. ${ }^{5}$

Pengelompokan berdasarkan jenis kelamin didapatkan perbedaan jumlah responden berjenis kelamin laki-laki dan perempuan, dimana karyawan laki-laki lebih banyak daripada responden perempuan. Menurut pengelompokan pendidikan terakhir responden, didapatkan paling banyak responden dengan pendidikan terakhir SMA / SMEA / SMK / STM. Penelitian Ambada, didapatkan responden terbanyak dengan pendidikan terakhir SMA. ${ }^{6}$ Selain itu, menurut pekerjaan responden didapatkan bahwa jumlah responden terbanyak pada bagian Universitas.

\section{Gambaran Penggunaan Antibiotik}

Dari hasil penelitian, diperoleh sebagian besar responden menggunakan antibiotik Amoxycillin $(91,2 \%)$. Beberapa responden menggunakan Cefadroxil (5,3\%), Tetracycline (2,6\%), Ciprofloxacin $(0,9 \%)$. Tidak ada jenis antibiotik lain yang pernah dikonsumsi oleh 114 responden dalam penelitian ini. Berdasarkan penelitian Atmadinata, Nasution, dan Novitasari, golongan cephalosporin merupakan antibiotik yang paling banyak digunakan. ${ }^{7}$

Dalam penelitian ini, didapatkan ketepatan dosis 100\%, ketepatan frekuensi minum obat 88,6\%, dan ketepatan lama pemberian obat 93,9\%. Ketepatan penggunaan antibiotik pada penelitian ini sejalan dengan penelitian Lisni, Iriani, dan Sutrisno, dimana ketepatan dosis 96,49\% dan ketepatan lama pemberian obat $87,72 \% .{ }^{8}$ Responden mendapatkan obat $92,1 \%$ dari dokter dan $7,9 \%$ dari warung.

Sebanyak 68,4\% responden yang mengonsumsi antibiotik tidak ada keluhan. Efek samping pemberian antibiotik yang dialami responden adalah $17,5 \%$ mual muntah dan $14 \%$ diare. Menurut penelitian Fithriya, 48\% responden tidak ada keluhan. Sebanyak $42 \%$ responden Fithriya mengalami efek samping alergi. ${ }^{9}$ Hasil pengobatan responden dengan antibiotik 93,9\% 
sembuh dan 6,1\% tidak sembuh. Responden yang tidak sembuh dalam pengobatan akan menghentikan pengobatan, berkonsultasi dengan dokter, dan menunggu hingga sembuh sendiri.

Pada penelitian ini, didapatkan penggunaan antibiotik yang sudah tepat pada karyawan sebesar $70,2 \%$. Responden selalu menggunakan antibiotik ketika sakit $(28,1 \%)$ dan menggunakan antibiotik setelah berkonsultasi ke dokter $(91,2 \%)$. Sekitar 8,8\% responden masih membeli antibiotik di warung dan 10,5\% sering menggunakan sisa antibiotik dari resep sebelumnya.

Setelah memperoleh informasi mengenai antibiotik dari dokter atau apoteker (93\%), responden menghabiskan antibiotik yang diberikan oleh dokter (70,2\%). Responden akan segera minum obat sesuai dosis saat lupa meminum antibiotik (71,9\%). Ketika mengalami efek samping dari antibiotik tersebut, 89,5\% responden akan segera berobat ke dokter. Sekitar 19,3\% menggunakan antibiotik saat batuk dan pilek. Sebagian besar responden memilih jenis antibiotik yang sering digunakan oleh keluarganya (43\%).

Dari hasil penelitian, sebanyak 70,2\% responden terkategori sudah tepat, $21,9 \%$ responden terkategori kurang tepat, dan $7,9 \%$ responden terkategori tidak tepat dalam menggunakan antibiotik. Hasil penelitian ini sejalan dengan penelitian Misriana yang berjudul "Pengkajian Kualitas Penggunaan Antibiotika Pada Pasien Bedah Appendix di RSUP Fatmawati Jakarta Tahun 2012”. Latar belakang penelitian Misriana adalah penggunaan antibiotik yang tidak tepat dapat meningkatkan biaya rumah sakit, biaya obat, toksisitas obat, resistensi antibiotika, dan biaya laboratorium. ${ }^{5}$

Dari 218 responden, didapatkan distribusi karakteristik responden berdasarkan usia dan jenis kelamin. Responden terbanyak yang terlibat dalam penelitian Misriana adalah perempuan (57,8\%). Responden terbanyak berumur 18-60 tahun $(63,76 \%)$. Berdasarkan hasil penelitian tersebut, penggunaan antibiotik sudah tepat $84,63 \%$, penggunaan antibiotik kurang tepat $3,3 \%$, dan penggunaan antibiotik tidak tepat $14,15 \% .{ }^{5}$

Penelitian ini menggunakan parameter yang berbeda dengan penelitian Misriana. Parameter pada penelitian Misriana berupa metode Gyssens. Penelitian ini menggunakan sistem skoring yang didapatkan dari pertanyaan kuesioner, dimana jawaban benar bernilai 1 dan jawaban salah bernilai 0 . Penggunaan antibiotik pada penelitian ini $(70,2 \%)$ dan penelitian Misrina $(84,63 \%)$ sudah tepat. ${ }^{5}$

\section{Pengetahuan Mengenai Antibiotik}

Pada penelitian, diperoleh $47,4 \%$ karyawan Universitas Tarumanagara berpengetahuan baik tentang antibiotik. Sebagian besar responden menganggap bahwa antibiotik dapat mengobati semua penyakit $(18,4 \%)$ dan mereka harus mengonsumsi antibiotik saat demam $(39,5 \%)$.

Beberapa responden yang mengetahui kegunaan antibiotik masih banyak keliru antara penggunaan untuk infeksi bakteri $(79,8 \%)$ dan infeksi virus $(69,3 \%)$. Menurut penelitian Ling OA et al, didapatkan sekitar $76,7 \%$ responden mengetahui antibiotik digunakan untuk mengobati infeksi bakteri Namun, 67,2\% responden masih salah menganggap antibiotik dapat mengobati infeksi virus. ${ }^{10}$ Masyarakat seringkali diresepkan antibiotik saat mereka terinfeksi virus. Umumnya, penyakit yang disebabkan oleh infeksi virus self-limiting dan tidak membutuhkan pengobatan tertentu. ${ }^{11}$ 
Responden mengetahui bahwa antibiotik harus diminum sampai habis $(83,3 \%)$, digunakan sesuai dengan petunjuk dokter $(94,7 \%)$, dibeli dengan resep dokter $(76,3 \%)$, dan harus diminum secara teratur tanpa putus $(71,9 \%)$. Namun, responden masih kurang tahu mengenai dosis dan bentuk sediaan antibiotik. Dosis antibiotik oral yang diketahui responden hanya $500 \mathrm{mg}(28,9 \%)$. Bentuk sediaan antibiotik yang diketahui responden hanya tablet dan sirup $(61,4 \%)$.

Responden berpendapat bahwa antibiotik spektrum luas sangat efektif dalam pengobatan sehingga diminum 1 kali sehari (36\%). Antibiotik ini bersifat aktif terhadap berbagai jenis bakteri, bakteri gram positif dan gram negatif. Antibiotik spektrum luas biasanya diberikan untuk penyakit yang belum diketahui bakteri penyebabnya, resistensi terhadap antibiotik spektrum sempit, dan keadaan superinfeksi. ${ }^{12}$

Antibiotik merupakan golongan obat keras. Obat ini hanya dapat dibeli di apotek dengan resep dokter. Golongan obat keras diberi tanda khusus berupa huruf K dalam lingkaran merah dengan garis tepi berwarna hitam. ${ }^{13}$ Sekarang, banyak masyarakat yang mendapatkan antibiotik secara bebas di warung $(18,4 \%)$. Antibiotik harus dibeli di apotek $(94,7 \%)$. Antibiotik secara umum diminum 3 kali sehari selama 7 hari (36\%). Masih ada responden yang menganggap antibiotik yang mahal menjamin kesembuhan suatu penyakit $(12,3 \%)$.

Sekitar 34,2\% responden mengetahui bahwa antibiotik dapat diminum bersama teh. Teh mengandung kafein yang dapat meningkatkan tekanan darah dan denyut jantung (sementara). Penggunaan antibiotik golongan kuinolon dapat memperpanjang efek kafein yang ada di dalam teh terhadap tubuh kita. ${ }^{14}$

Efek samping yang sering didengar dari responden adalah telinga berdenging bernada tinggi $(21,1 \%)$. Namun berdasarkan hasil penelitian, efek samping yang dialami oleh responden adalah mual muntah $(17,5 \%)$ dan diare (14\%). Sebagian besar responden $(92,1 \%)$ sudah sangat mengenal jenis antibiotik seperti Amoxycillin, Cefadroxil, dan Tetracycline.

Penggunaan antibiotik yang kurang tepat dapat menyebabkan resistensi (78,9\%). Resistensi banyak terjadi di masyarakat karena penggunaan dan peresepan yang tidak tepat. Ketidaktepatan penggunaan antibiotik antara lain tidak membeli antibiotik yang diresepkan, menyimpan antibiotik untuk pengobatan berikutnya, dan frekuensi minum antibiotik yang tidak sesuai. Ketidaktepatan peresepan antibiotik antara lain durasi dan dosis antibiotik yang tidak tepat, resep yang tidak memerlukan antibiotik, dan pemilihan antibiotik yang tidak sesuai indikasi. ${ }^{15}$

Responden yang resisten terhadap suatu antibiotik akan mengganti dengan golongan antibiotik yang sama (28,9\%). Ketika terjadi resistensi, sebaiknya dilakukan uji kepekaan antibiotik untuk mengetahui kemampuan obat untuk membunuh bakteri penyebab. Jenis antibiotik yang masih sensitif ini akan digunakan sebagai terapi pengobatan pengganti. ${ }^{16}$

Dari hasil penelitian, sebanyak $26,3 \%$ berpengetahuan sangat baik, $47,4 \%$ berpengetahuan baik, $15,8 \%$ berpengetahuan cukup, $8,8 \%$ berpengetahuan kurang, dan $1,8 \%$ berpengetahuan tidak baik. Hasil penelitian ini sejalan dengan penelitian Ambada yang berjudul "Tingkat Pengetahuan Tentang Antibiotik Pada Masyarakat Kecamatan Pringkuku Kabupaten Pacitan". Latar belakang penelitian Ambada adalah penggunaan antibiotik yang seringkali tidak tepat dan menyebabkan peningkatan resistensi kuman terhadap antibiotik. ${ }^{6}$ 
Dari 96 responden, didapatkan distribusi karakteristik responden berdasarkan usia, jenis kelamin, pendidikan terakhir, dan pekerjaan. Responden terbanyak yang terlibat dalam penelitian ini adalah perempuan $(78,13 \%)$ dan berumur $26-35$ tahun $(38,54 \%)$. Selain itu, didapatkan paling banyak responden dengan pendidikan terakhir SMA $(39,58 \%)$ dan pekerjaan wirausaha $(28,12 \%)$. Berdasarkan hasil penelitian tersebut, masyarakat berpengetahuan baik sebanyak $38,5 \%$, berpengetahuan cukup sebanyak $23,96 \%$, berpengetahuan kurang sebanyak $26,04 \%$, dan berpengetahuan tidak baik sebanyak $11,45 \%{ }^{6}$

Penelitian ini menggunakan parameter yang sama dengan penelitian Ambada. Parameter yang digunakan berupa skoring tingkat pengetahuan yang didapatkan dari pertanyaan kuesioner, dimana jawaban benar bernilai 1 dan jawaban salah bernilai 0 . Tingkat pengetahuan responden mengenai antibiotik pada penelitian ini $(47,4 \%)$ dan penelitian Ambada $(38,5 \%)$ baik. $^{6}$

\section{KESIMPULAN DAN SARAN}

- Jenis antibiotik terbanyak yang dikonsumsi responden adalah Amoxycillin (91,2\%).

- Ketepatan penggunaan antibiotik berupa ketepatan dosis $100 \%$, ketepatan frekuensi minum obat $88,6 \%$, dan ketepatan lama pemberian obat $93,9 \%$.

- Sebanyak $68,4 \%$ responden yang mengonsumsi antibiotik tidak ada keluhan.

- Responden mendapatkan antibiotik dari dokter $(92,1 \%)$.

- Tingkat kesembuhan hasil terapi antibiotik adalah 93,9\%.

- Penggunaan antibiotik pada sebagian besar responden sudah tepat.

- Sebagian besar karyawan Universitas Tarumanagara sudah mengetahui dengan baik mengenai antibiotik.

\section{REFERENSI}

Dorland WAN. Kamus Kedokteran Dorland. Edisi 31. Jakarta: EGC; 2010.

Widayati A, Suryawati S, de Crespigny C, Hiller J. Self Medication With Antibiotics In Yogyakarta City Indonesia: A Cross Sectional Population-based Survey. BMC Research Notes [Internet]. 2011 [cited 22 August 2015];4(1):491. Available from: http://www.biomedcentral.com/1756-0500/4/491

Ain H, Septian F. Perilaku Masyarakat Terhadap Penggunaan Antibiotika Oral [Internet]. 7th vol. Medica Majapahit; 2015 [cited 12 July 2015]. Available from: http://ejurnalp2m.stikesmajapahitmojokerto.ac.id/index.php/MM/article/download/11/9

Gusnellyanti E. Mencerdaskan Masyarakat Dalam Penggunaan Obat Melalui Metode Cara Belajar Insan Aktif (CBIA) [Internet]. Direktorat Jenderal Bina Kefarmasian dan Alat Kesehatan. 2015 [cited 20 July 2015]. Available from: http://binfar.kemkes.go.id/2014/09/mencerdaskan-masyarakat-dalam-penggunaan-obatmelalui-metode-cara-belajar-insan-aktif-cbia/

Misriana. Pengkajian Kualitas Penggunaan Antibiotika Pada Pasien Bedah Appendix di RSUP Fatmawati Jakarta Tahun 2012. Jakarta: Program Studi Farmasi Fakultas Kedokteran dan Ilmu Kesehatan Universitas Islam Negeri Syarif Hidayatullah Jakarta; 2013.

Ambada SP. Tingkat Pengetahuan Tentang Antibiotik Pada Masyarakat Kecamatan Pringkuku Kabupaten Pacitan. Surakarta: Fakultas Farmasi Universitas Muhammadiyah Surakarta; 2013.

Atmadinata DA, Nasution I, Novitasari A. Studi Deskriptif Pemakaian Antibiotik di Rumah Sakit Roemani Periode Januari 2011 Sampai Juni 2011 di Instalasi Penyakit Dalam Bangsal Khodijah. Semarang: Fakultas Kedokteran Universitas Muhammadiyah Semarang; 2012. 
Lisni I, Iriani SO, Sutrisno E. Evaluasi Penggunaan Antibiotik Pada Pasien Faringitis Di Suatu Rumah Sakit Di Kota Bandung. Bandung: Sekolah Tinggi Farmasi Bandung; 2015.

Fithriya S. Hubungan Karakteristik Orang Tua Dengan Pengetahuan Dalam Pemberian Antibiotik Pada Anak Di Dusun Sonotengah Kabupaten Malang. Jakarta: Program Studi Ilmu Keperawatan Fakultas Kedokteran dan Ilmu Kesehatan Universitas Islam Negeri Syarif Hidayatullah Jakarta; 2014.

Ling Oh A, Hassali MA, Al-Haddad MS, Syed-Sulaiman SA, Shafie AA, Awaisu A. Public Knowledge and Attitudes Towards Antibiotic Usage: A Cross-Sectional Study Among The General Public In The State of Penang, Malaysia [Internet]. PubMed. 2011 [cited 19 May 2016]. Available from: http://www.ncbi.nlm.nih.gov/pubmed/21628809

Anderson L. Viral Infections - Why Antibiotics Kill Viruses? [Internet]. Drugs.com. 2015 [cited 12 May 2016]. Available from: http://www.drugs.com/article/antibiotics-and-viruses.html

Broad Spectrum Antibiotics [Internet]. New Health Guide. [cited 12 May 2016]. Available from: http://www.newhealthguide.org/Broad-Spectrum-Antibiotics.html

Kementerian Kesehatan RI. Pedoman Penggunaan Obat Bebas dan Bebas Terbatas [Internet]. Direktorat Bina Farmasi Komunitas Dan Klinik Ditjen Bina Kefarmasian dan Alat

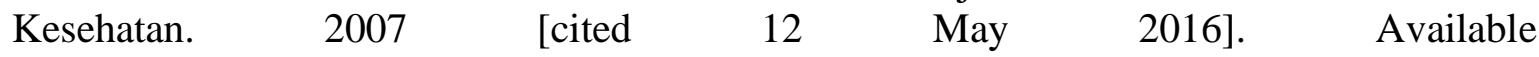
from:http://pio.binfar.depkes.go.id/PIOPdf/PEDOMAN_OBAT_BEBAS_DAN_BEBAS TERBATAS.pdf

Tomaka N. Food and Drug Interactions [Internet]. GDAFT. [cited 14 May 2016]. Available from: http://www.gdatf.org/about/about-graves-disease/patient-education/food-and-druginteractions/

Antibiotic Awareness [Internet]. NHS. [cited 14 May 2016]. Available from: http://www.nhs.uk/nhsengland/arc/Pages/AboutARC.aspx

Wu B, Case-Lo C, Kim S. Sensitivity Analysis [Internet]. Healthline. [updated 24 February 2016, cited 14 May 2016]. Available from: http://www.healthline.com/health/sensitivityanalysis\#Overview1 